Each step in the detective investigation contributes to our understanding of these same issues today. At the height of the French Revolution, for instance, Alexandre Lenoir became the self-appointed custodian of the human remains and historic relics preserved across France in churches and chapels, volunteering to rescue them from the desecration of the marauding mobs and place them in his own 'hall of antiquities' for safe keeping. He went about his task with revolutionary - or perhaps, Shorto suggests, religious - zeal, assembling huge quantities of stonework and statuary, and logging its acquisition with care.

As reason replaced faith in the new French Republic, Lenoir rescued the bones of France's greatest rationalist from the church of St Geneviève in Paris where they had lain since de Terlon recovered them from Sweden. Meanwhile, on the eve of the Terror, a French revolutionary committee decreed that the bones should be moved to the Pantheon - the new secular cathedral of the revolution - and a statue erected to Descartes' memory. Not for the first time, however, events overtook the best of intentions. In spite of an official decree of the ruling National Convention, the bones stayed in Lenoir's macabre museum, where he laid out his tombs and funerary statuary in a pleasure garden in which visitors could wander at will and "ponder beauty and death".

Once again, the whereabouts of Descartes' bones become shrouded in mystery. It is not even clear that Lenoir's rescued remains were those of the father of rationalism. Nor is it clear what happened to them thereafter. They seem to have gone missing among the carefully documented treasures in Lenoir's museum.

For Shorto, his own fascination with this curious piece of narrative history is a mirror for the concerns of each and every one of us, bewildered by modernity and struggling to find meaning and belief in a confusing world. His piecing together of the fortunes of Descartes' bones is elegantly interwoven with the intellectual history of Cartesian philosophy and beliefs, as well as with the history of the uncomfortable relationship between Catholicism and Cartesianism. His suggestion is, I think, that we cannot escape from our felt need for faith and devotion, and that, deprived of religious relics we turn to secular forms of worship.

I am not sure that our attitude to mortal remains has not always sat apart from the rest of our thinking and feeling - a place of talisman and taboo that brings out in us, from the depths of our soul as it were, our most primitive, elemental feelings and attitudes, however rational our outlook.

Between 1640 and 1660, for example, an English gentleman named John Bargrave embarked on a 'grand tour' of Europe in search of unusual items to assemble in a fashionable cabinet of curiosities. When he returned to England he became a canon of Canterbury Cathedral, to which he bequeathed his carefully catalogued collection. The Bargrave cabinets can still be seen there today. It is, in a way, a biography in a box, testifying in its varied items to Bargrave's personal passions and interests. There is a beautifully constructed model of an eye, which can be dismantled to show its inner structure. There are 34 saints' bones bought for 2 shillings and 6 pence (about $\mathfrak{£ 2 0 0}$ or US $\$ 350$ today). There are tiny antique statues, rings, trinkets, each lodged in its own drawer and accompanied by a description of what it is and where it was found.

Just as in the case of Descartes' bones, Bargrave's cabinets reveal an intense fascination on Bargrave's part for relics and human remains. One of the items in it - which I have myself, somewhat tremulously, handled - is 'the finger of a Frenchman'. Bargrave's catalogue tells us of the "danse macabre" put on for him at the monastery at Toulouse where he acquired it and where "all the dead men and women's corpses that are buried there are dried into a kind of mummy". He wrote: "They showed us the corpse of a physician (of their acquaintance), which, when they put a clean piece of paper into one hand and a pen into the other, stood in such a posture as if he had seriously been a-writing a dose or prescription."

Bargrave's macabre trophy is a reminder of our enduring fascination with remnants and reminders of our own mortality. Shorto's beautifully written book does likewise - the reader will find its intellectual insights entertaining, enlightening and, perhaps, disturbing. Lisa Jardine is director of the Centre for Editing Lives and Letters and centenary professor of Renaissance Studies at Queen Mary, University of London, London E1 4NS, UK. Her latest book is Going Dutch: How England Plundered Holland's Glory.

\title{
Psychology's pet subject
}

\section{Alex \& Me: How a Scientist and a Parrot Discovered a Hidden World of Animal Intelligence - and Formed a Deep Bond in the Process \\ by Irene Pepperberg \\ HarperCollins: 2008.240 pp. $\$ 23.95$}

Alex and $\mathrm{Me}$ is the conjoined life story of cognitive psychologist Irene Pepperberg and her African grey parrot, Alex. Pepperberg sketches her life from lonely girlhood in Brooklyn, New York, through college and graduate school - she attended the Massachusetts Institute of Technology aged 16, and gained $\mathrm{PhD}$ in theoretical chemistry at Harvard University - to her acquisition of Alex in 1977. Pepperberg helped Alex to develop the use of spoken words to identify numbers, colours, materials, shapes and categories of objects. She struggled to gain respect and recognition from the academic community for her work, and this takes centre stage in her account.

The book starts and ends with Alex's death in September 2007. The public response to his demise underscored his celebrity status. Outpourings of grief reached Pepperberg from all around the world - even The Economist ran an obituary. She conveys effectively her shock at losing not just her main research subject, but

\section{New Theories of Everything} by John D. Barrow (Oxford Univ. Press, £8.99) Updating his 1991 work, Theories of Everything, Barrow looks at the latest discoveries and theories about the Universe and explores their philosophical and cultural implications. He shows how the search for a Theory of Everything leaves us more aware of the richness and complexity of the cosmos.

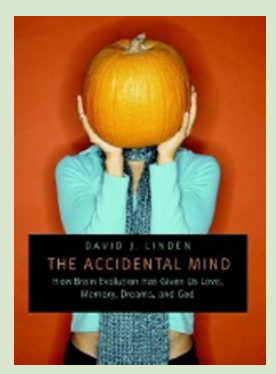

The Accidental Mind: How Brain Evolution Has Given Us Love, Memory, Dreams, and God by David J. Linden (Harvard Univ. Press, \$17.95) Linden's introduction to brain science is enjoyable and accessible. "Even readers trained in neuroscience are likely to enjoy the many tidbits of rarely taught information - on love, sex, gender, sleep and dreams - that spice up Linden's main argument," wrote reviewer Georg Striedter (Nature 447, 640; 2007). 


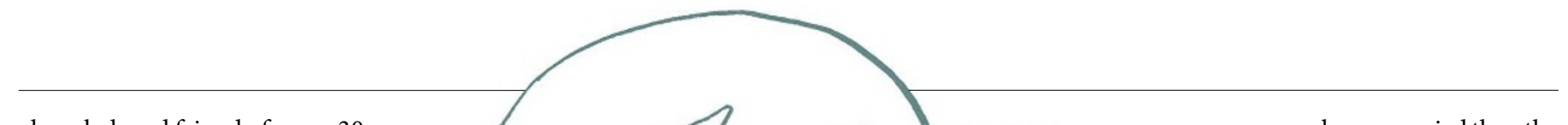

also a beloved friend of some 30 years.

Similarly to many scientists whose lives revolve largely around their work, Pepperberg is impatient with her critics. She bemoans the reviewers of her work who force her to carry out more experiments when the results are already abundantly clear, and the funding agencies that fail to see the importance of her project. She calls their criticisms "denigrating". Yet there are many good reasons to be sceptical of the exceptional abilities of a single animal.

More than 350 years ago, the philosopher René Descartes suggested that there was a fundamental difference between "teach[ing] a magpie to say good-day to its mistress, when it sees her approach" and the verbal expression of ideas by human beings. The magpie, declared Descartes, does not form words as expressions of its thoughts, only as responses to obtain a desirable reward, learnt through training.

Pepperberg insists that her work with Alex puts the final nail in Descartes' coffin, and shoos away the criticism of the behaviourists who are Descartes' heirs. She quotes her last interchange with Alex on the night before his death: "You be good," said Alex. "I love you."

Although she admits that her students would sometimes teach Alex entertaining sayings in the manner that Descartes suggested, she insists that her relationship with Alex was truly one of reciprocated affection. However, before concluding that a parrot proclaiming love knows whereof he squawks, one would want to be certain that nobody has been giving the bird a titbit for what he says.

A century ago in Berlin, a respected school

teacher presented to the public a horse known as Clever Hans, who had the apparent intelligence of a 13-year-old child. A prestigious commission of experts was convinced that Hans could solve school-level arithmetic problems. However, psychology student Oskar Pfungst demonstrated that the horse was not answering the questions as posed, but instead responding to the subtle head movements of those who asked the questions. The movements were so slight the questioners did not know they were making them, and there was no suggestion that the horse's owner had intentionally taught Hans to respond to them. Can we be confident that Alex was not deducing the correct response from subtle cues the experimenters were giving off?

One defence against the accusation that Alex was just another Clever Hans is that his

responses were much more varied than the foot stomping that Hans used to answer questions. Whereas Hans only needed to be cued to start and stop moving his hoof, Alex needed to say many different things to answer a question correctly. However, the fact that Pepperberg always remained in the room to interpret Alex's utterances poses problems for this defence. We know that the human ear is easily tricked. Led Zeppelin's Stairway to Heaven contains satanic lyrics when played backwards - but only if the words are shown to the listener. Without a script, the reversed sounds are perceived as nothing more than mixed-up phonemes. The squawking of a parrot often contains jumbled speech sounds, so the form these take to a listener might well depend on what that person expects to hear.

Alex and $\mathrm{Me}$ is an engaging narrative because it has the intimate relationship between one human and one parrot at its centre. But as an exploration in science, it is deeply worrying that nobody can replicate its central findings, given the ease with which the subjects and equipment can be acquired. Even Pepperberg has been unable to replicate Alex's achievements using other parrots.

Alex may have had some sense of number, shape, colour and material. Similar results have been obtained with pigeons, so it is not an absurd conjecture. For those who did not know him personally, the tragedy of Alex's passing is that the records that remain are not enough to prove the case one way or the other.

Clive Wynne is associate professor of psychology at the University of Florida, Gainesville, Florida 32601, USA, and author of Do Animals Think? e-mail:wynne@ufl.edu

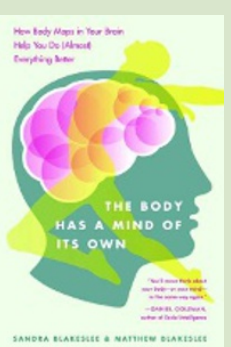

The Body Has a Mind of Its Own: How the Body Maps in Your Brain Help You Do (Almost) Everything Better

by Sandra Blakeslee and Matthew Blakeslee (Random House, \$15.00)

This book explores the emerging science of mind-body connections. "Ideas from sister disciplines, including neurology, psychiatry and cultural anthropology, mix comfortably with laboratory observations," wrote Edvard Moser (Nature 449, 406; 2007).

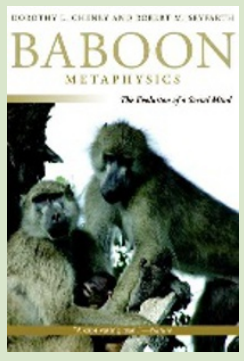

\section{Baboon Metaphysics: The Evolution of a Social Mind}

by Dorothy L. Cheyney and Robert M. Seyfarth (Univ. Chicago Press, \$18.00)

Cheyney and Seyfarth examine the dynamics of baboon society. "Their enthusiasm is obvious, and their knowledge is vast and expressed with great clarity," wrote Asif A. Ghazanfar. "It will get you thinking - and maybe spur you to travel to Africa to see it all for yourself." (Nature 448, 535-536; 2007). 